Article

\title{
Housing Activism Initiatives and Land-Use Conflicts: Pathways for Participatory Planning and Urban Sustainable Development in Bucharest City, Romania
}

\author{
Mariana Nae, Liliana Dumitrache *, Bogdan Suditu and Elena Matei \\ Faculty of Geography, University of Bucharest, 1.Blv. Nicolae Bălcescu, Bucharest 010041, Romania; \\ mirellanae@gmail.com (M.N.); b_suditu@yahoo.fr (B.S.); elena.matei@g.unibuc.ro (E.M.) \\ * Correspondence: dosaredumitrache@yahoo.com; Tel.: +40-21-305-3844
}

Received: 1 October 2019; Accepted: 4 November 2019; Published: 6 November 2019

check for updates

\begin{abstract}
This paper presents a geographical perspective of the phenomena of housing activism and land-use conflicts per se. It focuses not only on their spatial manifestations, but also on the complexity of the perceived meanings, values, and the power relationships among the involved parties, rooting into activist geographies. The research methodology was based on two complementary methods: frame analysis to observe the emergence, sources of land-use conflicts, and nature of the relationships between the actors involved; and discourse analysis to explore the social interactions and power relations between structures and practices related to housing activism. For a more inclusive perspective on the sources of land-use conflicts and housing activism initiatives in Bucharest, we used a combination and triangulation of various sources and modes of data collection. Compared with other European cities with active civic engagement, this phenomenon is still emerging in Bucharest. Although conflicts are numerous, the civic initiatives are still fragmented and fail to generate a vision and implementable public policy. However, multiple assaults on urban spaces (green areas, historically protected areas) have resulted in more actions and actors (individual or organised) becoming civically engaged. The article contributes to the environmental debates that stress housing activism as a pathway to participatory planning initiatives.
\end{abstract}

Keywords: housing activism; land-use conflicts; participatory planning; civic initiative groups (CIG); awareness-triggering strategies; Bucharest City

\section{Introduction}

The sensitive problems related to the sustainable development of cities, high densification, continuous degradation of the living environment, and the urban sprawl process have triggered debates among the researchers in the field of social sciences. The subject is topical and may be of great interest for all actors involved, as well as from the perspective of spatial effects. However, the way these conflicts arise and develop in specific circumstances remains challenging to determine and to explain, as the existing literature does not provide a theoretical and empirical framework to grasp how land-use conflicts emerge, as well as their typology and particularities [1-3].

Therefore, urban space, resources, and land-use become the subject of tensions or conflicting situations through various development projects or strategies.

From the wide range of conflicts, special attention was paid to those associated with changes in the use of land or environmental conflicts; this is mainly because of the territoriality, especially to their geographical dimension, as these problems determine manifestations, stages, and consequences at a spatial level: land-use speculation, high-densification of urban areas, environmental issues, or loss of green spaces $[4,5]$. Land-use conflicts represent the effects of the dissatisfaction of one group or 
part of the community with the actions initiated or planned by another group, their neighbours, public authorities, or private investors [6-8].

On the one hand, the core historical areas of cities have always been the targets of strategic planning and urban development objectives, especially if they hold and still preserve high functional and patrimonial significance, with increasing aesthetic value and symbolic heritage. Downtowns of many cities have been re-aestheticized as corporate landscapes of leisure $[9,10]$.

On the other hand, urban fringe areas, as potential resources for urban reconversion and regeneration, have been the subject of typical development strategies [11,12]. Over time, in some situations, these spaces have become areas/spaces of contestation, for which housing activism and several civic initiatives have risen and been manifested.

Conflicts in land-use entail social relations and processes; they have distinctive characteristics, but also divergent interests/visions of the parties concerned. Understanding land-use changes means understanding the social processes driving them [13]. In order to mediate or avoid tensions or conflict events, general and local spatial and planning policies need to be well-coordinated, and decision-makers must have the ability to control conflicts or initiate substantial improvements in land-use planning and management decisions.

Therefore, strengthening participatory planning becomes imperative; the engagement of citizens in decision-making is considered beneficial when the adopted decisions influence, in particular, the living environment, the identity, and the sense of the place or the community/neighbourhood in which they live [14-18]. Thus, residents are more willing to engage in decision making effectively or give rise themselves to proactive civic actions.

The CEECs (Central Eastern European Countries), as former socialist regimes, faced many challenges raised by the new socio-spatial organisation and spatial planning, that is, the evolution and transformations in land-use and property resulted mostly from the changing role of the actors involved in the planning processes and decision-making. The transfer from the collective state property to the individual, private one has outlined this particularism in general lines. These countries had to cope with the challenges of a triple transition: to the new political regime, to the market economy, and to democratic governance [19-22].

In the context of profound political and economic changes, since the early 1990s, with the turn from socialist uniformising mechanisms to the diversity of post-socialist neo-liberal initiatives, the paradigm shift in the field of urban development and planning has shaped the platform of action for both the aggression on the urban land and housing activism and between the action of public authorities and the offence of speculative developers or other investors who are willing to transcend the rules in order to obtain direct particular constructive or economic advantages. In most cases, these advantages allowed additional floors for buildings, excessive construction densities, and claims to build without complying with the norms of law.

Investigation of land-use changes associated with participatory planning involves integrative research methods and a new vision in approaches. While land-use changes intertwined with social interaction and human activities impact urban system organisation, a comprehensive understanding of processes is needed. As a result of multiple interactions between the population and living environment, at different geographical scales, land-use studies have become essential for environmental and climate changes, as well as for the urban or rural land conversion. Planning professionals became more interested in developing methods and tools that combined computer technologies and geo-information, better known as the syntagma 'planning support systems' (PSSs). A PSS is a combination of planning-related theory, data, information methods, and instruments that takes the form of an integrated framework with a shared graphical interface [23,24]. Quantitative approaches have offered provocative insights on fusing social and human behaviour, social interaction, land-use changes, and participatory planning. Various sophisticated methods and techniques have been carried out with a central emphasis on an integrated system modelling approach. However, 'the socio-ecological modelling framework is an emerging paradigm in the complex urban system and sustainability 


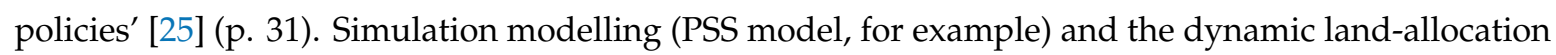
model provide an accurate scientific background for land-use planning and guidance in participatory planning [26,27].

A mixed-method PPGIS (participatory planning and GIS/Geographic Information System). develops new approaches in researching potential land-use conflicts. Increasing interest was paid to participatory mapping as an innovative approach to identify and depict conflict potential for different types of land-use with 'landscape values' [28]. This approach privileged the mapping preferences where the spatial locations of different types of land became acceptable or not for the participants $[29,30]$.

In Romania, researchers' interest in the subject of land-use conflicts is rising; they addressed various issues, either of a conceptual nature, in the process of land use planning, emphasizing anticipation and negotiation, or of applied character, based on multi-criteria analysis.

Hersperger et al. [31] outlined a comprehensive approach to understanding conflicts in the land-use planning process, stressing the importance of conflict-determining factors. A series of techniques with practical value for decision-makers are increasingly being applied. Using multi-criteria analysis, Iojă et al. [32] proposed a tool for integrating land-use conflicts into the spatial planning strategies for the metropolitan area of Bucharest. The findings suggest that geographical proximity plays a central role, while spatial indicators have revealed a high probability of land-use conflicts in the proximity of Bucharest.

The research on land-use inevitably focuses on production and consumption activities and on services flows, which depend on spatial arrangements and the allocation of land resources. Spatial analysis of land resources and evaluation of spatial planning outcomes are inextricably linked. Particular emphasis was given to assessing the implementation of national spatial planning objectives.

An evaluation framework was designed to examine the compliance of national planning objectives with the results, and several planning strategies were identified [33,34]. Also, the conflict between conservation, communities, and economic activities was analysed. Using an ACR framework (anticipation-characterisation-resolution), relevant indicators have been proposed to evaluate the environmental conflicts in the Natura 2000 network [35]. Some authors have focused on the problems of agricultural land-use, land grabbing, and conflict management [36,37].

However, qualitative approaches were less applied in order to find how the structures of meaning and actions for mobilising civic actors are central, or it is essential to understand the experience of actors.

Compared with other European cities, with practices and experience in the field, where land-use allocation and policies were better regulated, participatory planning was encouraged [38], and civic engagement was more active, this phenomenon is still emerging in Bucharest. Social or environmental changes are the catalyst for land-use conflicts [28,39]. These civic initiatives have coagulated substantially on the strength of the grassroots protest movements on ecological issues [40,41].

This paper aims to present a geographical perspective of the phenomenon of housing activism and land-use conflicts per se. Our research identifies and analyses the typologies of civic actions, specific to each area (centre, peri-centre, and new periphery), thus supporting the correlation between land-use dynamics and civic involvement of the residents. To better understand the dynamics of land-use and civic activism specific to large cities in Romania, and mainly to Bucharest, three representative aspects need to be pointed out:

- (a) Most large cities consist of a quasi-similar concentric structure: a historical centre built until the end of the 19th century; a peri-centre developed from the end of the 19th century, until World War 2 (WW2), in which residential areas (aristocratic and proletarian), industrial, and public service areas (hospitals and cemeteries) alternate; an area of large neighbourhoods of socialist blocks and peripheral villages incorporated into the city before 1968; and new residences of the urban sprawl type and gated communities developed after 1990. The urban morphology of these distinctive areas within the city was shaped by the legislation in power at the time of their development, and further interventions, with a speculative derogatory character. Every new stage 
or intervention on the land-use regulations could be, at the time, the subject of local conflict and public reaction.

- (b) During the socialist period, the nationalisation of enterprises (1948) and urban dwellings (1950), the interdiction of land inheritance and transactions (1968), and the imposed restrictions related to the expansion of built-up space (Law No.58/1974 on systematisation of urban and rural localities) have dramatically ceased the dynamic of constructions in the old neighbourhoods and strengthened the role of the state, as the only actor of urban development. Meanwhile, the critical opinions and the expectations of residents, mostly state tenants, have been neglected. As well, during the last socialist decade, only the state was allowed to construct houses (block type) in the large cities, while the individual initiatives of the inhabitants to build houses were very limited, usually unauthorised and located in perimeters not declared yet as 'demolishable ' for future urban projects (neighbourhoods of blocks).

- (c) The so-called 'urban renovation' projects carried out in Romania after 1974 have led to the demolition of many central neighbourhoods. In most cases, blocks of a standard and poor architectural design replaced individual houses and quality villas. Subsequently, the local population was brutally relocated to peripheral blocks; this process was carried out without consultation, fairness, nor reasonable alternatives for the former owners of demolished houses. Under these circumstances, the demolition process has induced a collective psychosis to the generations of urban dwellers who have experienced 'urban renovation'; thus, the idea of demolitions and land-use interventions became the subject of conflict and civic interest.

In the first post-socialist decades and even today, terms related to the transformation of neighbourhoods and the replacement of buildings, such as 'demolition' and 'urban renewal', still have a negative connotation, reminiscent of the destructive-constructive interventions of the last socialist period. For the same reason, investors who generate land-use conflicts are often associated with the totalitarian regime, and housing activism is also an attitude, reactive and devoid of political obstacles, to the ancient dictatorial practices.

This paper starts from the idea that citizen engagement is positive and active in preserving the identity of places and neighbourhoods; besides, the involvement of residents in participatory planning is a desideratum, and the awareness strategies, conducted by groups of civic initiatives, provide the necessary background for residents to get involved in the city life/res publica.

The nature of the relationships between these groups and the residents of the neighbourhood community is particularly important. As these forms of manifestation and coagulation of civic initiative groups (CIG) are recent, an approach that considers opinions of both experts in the field and representatives of civic groups involved could provide interesting insights and further research directions of such a complex issue.

Therefore, we further operationalised the following research objectives: to emphasise the general context of land-use conflicts' occurrence, in accordance with the transformation of urban space in post-socialist Bucharest; to identify areas within the city that have generated land-use conflicts or could be potential source of conflict, as well as the typology of these conflicts; and to analyse the emergence of housing activism initiatives and their role in participatory planning.

\section{Materials and Methods}

As land-use conflicts are complex and fall within a specific socio-political and economic context, the qualitative approach is appropriate [42]. The research methodology was based on the complementarity of two methods: the frame analysis, following the approach of Shmueli [43], to observe the emergence, the sources of land-use conflicts, and the nature of the relations between the actors involved; and the discourse analysis (DA), which draws on the Foucauldian theory of power [44], to explore social interactions and power relations between structures and practices concerning the housing activism. 
Frame analysis is associated with content analysis in qualitative research and generally pursues the description of attributes of the communicative power of texts. A 'frame' provides not only a dimension of perceived reality, but also the interpretation and evaluation of it. Framing is based on selection and salience [45]. Framing includes several stages or framing functions: it defines the problems and finds a specific causality; requires a diagnosis, by identifying the factors that lead to the occurrence of problems, assessing the causes and effects; and proposes possible remedies and solutions.

Discourse analysis is an emerging cross-discipline [46]. Discourse analysis (DA) is an interpretive method that requires the analysis of text and discourse in terms of wording, grammar and textual composition, distribution, and production. This method allows a comprehensive understanding of social phenomena and focuses on explanations of how particular meanings are constituted.

The overall objective of discourse analysis lies in assessing how forms of subjectivity and power relations between discursive statements and practices construct a discourse.

Data and information on conflict analysis, the emergence, and typology remain insufficient and incomplete for various reasons: the real motives, sources, and circumstances of tensions, and then of conflict, the parties involved, or because the type of mediation or solutions to be adopted is not known from the outset. The approach is qualitative and multicriterial, in which several elements can be unfolded, following the guidelines proposed by Torre et al. and Khan et al. [47,48]: nature of the conflict; parties/stakeholders involved in the conflict (interests, relationships, salience); classifications of the conflict (manifestation, stage, and scale); and the current trend in the conflict. Land-use conflicts embrace various forms, and they have a history, as well as stages and manifestations. The methods of identifying and analysing land-use conflicts are diverse, and data collection is laborious, with each data source having its limits (subjectivity of expert opinions, media with agenda-setting, or ideological and political partisanship).

To identify the roots and typology of land-use conflicts, we used a 'combination and triangulation of different sources and modes of data collection' [47] (p. 5); that is, semi-structured interviews with the experts in the field, data from administrative litigation courts, in-depth interview with well-known housing-activist, reports of NGOs, (Non-Governmental Organisations) articles in newspapers on related topics, online blogs, web-pages, and spatial data in GIS environment (Table 1).

Table 1. Source and data information.

\begin{tabular}{cc}
\hline Official Reports of Professional Association OAR (Romanian Architects Order) & 2 (2018, 2019) \\
\hline Observatorul Urban Bucuresti (Bucharest Urban Observatory) & Archive 2009-2019 \\
Official reports of NGOs Asociatia Salvati Bucurestiul & 2 \\
Mass-media reports related to urban planning issues & 42 \\
Semi-structured interviews with experts in the field & 15 \\
Semi-structured interviews with representatives of NGOs & 5 \\
An in-depth interview with the leader of the NGO Asociația Salvati Bucurestiul & 1 \\
\hline
\end{tabular}

To have a more inclusive outlook on housing activism initiatives, we set out semi-structured interviews as a flexible method [49] with both experts in the field (15) and representatives of NGOs (5) regarding urban legislation issues, the emergence of potential conflicts, the character and the forms of organisation of civic initiative groups, the strategies applied in awareness-raising, lawsuits, and environmental legislation.

The experts identified and contacted through Universities Network and professional associations, such as OAR (Romanian Architects Order) and RUR (Registrul Urbaniștilor din România/The Register of Romanian Urban Planners), had experience in urban planning (five urban planners, six architects, and four geographers). Representatives of NGOs were contacted through the CeRe platform, (https: //cere.ong/), and semi-structured interviews were conducted based on a schedule (scheduled interviews). One in-depth interview was conducted with the leader of the most active NGO, Asociația Salvati 
Bucurestiul (Save the Bucharest Association). The interviews comply with ethical codes and guidelines for qualitative research.

The open-ended questions addressed to the experts focused on more specific issues concerning the urban planning legislation, on the high densification process and the environmental problems resulting from the residential development projects, projects being the subject of land-use conflicts and the effects, the role of the actors involved in the conflict, the evolution and impact of civic initiatives groups, and the stakes of participatory planning.

All the sources of data and texts (policies, legislation, official reports, and the transcripts of semi-structured interviews) and housing activism initiatives and programmes were analysed following the analytical framework and discourse analysis. A part of the discourse analysis process involved a coding or indexing exercise, implying a mechanism for thinking about the meaning of data collected [50]. The coding was manually conducted, and texts were coded according to their meanings and origins. Another part implied the selection and interpretation of emerging themes. The emerging categories are essential and 'meaningful in relation to the data' and 'to the other categories' [51] (p. 96-97). A part of the textual analysis was performed using an open-source, web-based application, Voyant Tools v.2.4 (voyant-tools.org) [52].

Land-use conflicts mostly emerge where changes of land destination occur; to have a spatial perspective of potential sources of conflicts during the post-socialist period, as well as to observe the distribution of possible on-going or solved conflicts, two maps were created.

The maps were made in ArcGIS 10.3.1 ®(ESRI Redlands, CA, USA 2015), the Stereo 70 Projection, using the Corine Land Cover (CLC) 1990, 2012, and 2018 databases, uploaded into the EEA Central Data Repository, in order to identify, by overlap, the dynamics of land-use changes. We selected three reference years, 1990, at the early stages of market liberalisation; 2012, a peak year for Bucharest real estate projects; and 2018, the latest available. Mapped conflict cases were identified in the Court of Law List, being either under trial or resolved, through a definitive judicial resolution. They were georeferenced using the coordinates recorded in files and classified by types using the graduated symbols tool of Arc GIS software.

Our approach considers three significant analytical dimensions, continually evolving, dynamic, and interdependent during the post-socialist period: the legal-administrative dimension, used to describe and explain processes in the light of the changes of the juridical framework; the spatial dimension, focusing on the location of processes and types of investments, which generated or are potential sources of conflicts in distinctive areas of the city; and the civic-associative dimension, to observe its evolution in connection to land-use conflict, from the first protest movements to the first associative forms.

For the case of Bucharest, as these manifestations are considered emergent, our approach starts from the premise of the existing gap/hiatus between the actions and projects carried out by public authorities, private developers, and residents. These new development projects, on the background of the 'urban chaos' label detected in public discourse, can often be considered to be inadequate or inconsistent with residents' expectations and needs, or are not sufficiently transparent to the public interest. Once these inconsistencies have generated tensions or conflicts between the parties involved, from local and spontaneous protests, to various Court solutions, one can appreciate that they gain proper and specific substance, and benefit from local materiality and spatiality.

\section{Results and Discussions}

\subsection{Spatial Planning Challenges, New Master Plans, and Legislation: Breaking the Deadlock}

With a population of 2,121,794 inhabitants in 2019 [53], Bucharest is a dynamic South-Eastern European regional centre, with great business and investment potential. Urban spatial growth was slow in the early years of the transition process, but the city expanded rapidly after the year 2000 [54]. 
The spatial organisation of the city became a challenging and critical dimension $[55,56]$. The relationship between spatial planning and land-use, as well as how each component of strategic spatial planning, such as land-change intentions as expressed in plans, territorial governance, and external conditions interrelate with all the others [57,58], are often ignored. This explains the inaccuracies generated by the urban planning challenges and city spatial planning, the updating of the master plans, and the compromise of the derogatory urbanism regulations on the one hand, and of the urban and economic growth and the need to find solutions for urban regeneration and sustainable development on the other hand $[59,60]$.

For the city of Bucharest, in its new socio-spatial frame development, from the centralised, planned regime to a regulatory restructuring one, which produces geo-institutional differentiation across places [61], the challenges were mainly related to spatial planning, which mostly followed the typology of the post-socialist transformations. Considering this situation, planning legislation, norms, and institutions had to adjust to new power relations. Private developers, landowners, investors, and consumers soon became the new agents of change and property development [21]. Moreover, the absence of cohesive city development plans, the disregard of adequate planning strategies, and the abuse of exemptions from spatial planning laws had real long-term consequences on urban development.

Various legal and institutional factors have influenced the process of spatial planning, from which we discuss the most significant issues: (a) property transfers from public to private ownership; (b) lack or obsolescence of legal reforms in urban planning; (c) difficulties in the implementation of new master plans and urban tools for development; and (d) the changing role of public and private actors, as a result of new paradigms of planning and urban development.

- (a) Property (land and dwellings) transfers from public to private ownership

The ownership transfer process, from the abolition of private property through the 'nationalisation act' (1948 for business and industries; 1950 for dwellings) to the privatisation process during the 1990s, was crucial, but slow and difficult. A set of laws based on municipal self-governing mandated the transfer; however, it rapidly became evident that the authorities faced a lack of precise planning expertise, which inevitably led to conflicts, mostly generated by the issue of property rights in the overall scene of changing relations between the centralised systems and those based on a market economy [22].

In Bucharest, as in other cities in Romania, the following sources of change and urban conflict can be mentioned: the processes of restitution of nationalised lands and dwellings; the privatisation of the stock of flats built during the socialist period, but also of the nationalised dwellings to the tenants; the land reform; the privatisation and liberalisation of the agricultural land market in the outskirts; and the industry privatisation.

All these processes of the ownership transfer from public to private have led to the creation of a neoliberal real estate market, developed without an appropriate legal framework. Urban conflicts and the first signs of civic involvement emerged concomitantly with the malfunctions in the proposed or realised projects related to land-use investments.

- (b) The limitation and the obsolescence of legal reforms in urban planning

Local authorities considered updating their planning reforms and drafting new master plans to be a critical endeavour, even if, in the case of Bucharest, the master plan was elaborated on much later, in the year 2000.

Some of the following general context elements will help to better understand the situation.

The normative framework of the socialist period on urban and rural planning was abolished in December 1989, while the regulating frame devoted to constructions did not specify any private initiative in the field, detailing only the role and actions of the public sector. Thus, the creation of a new legal and institutional framework was very slow, incoherent, and with numerous gaps and 
limitations of public action, promoting, in the first stage, the immediate priorities of the investors (Law No. 50/1991 regarding the authorisation of constructions) [62], and much later ensuring the coherence of urban development and the protection of public interest (Law No. 350/2001) [63].

In the first post-socialist decade, legislation as well as authorities focused mostly on the individual construction and not on the urban setting in which they were built. Consequently, many large, aesthetic, and robust houses rose in the middle of agricultural land, unorganised from the urban point of view, without public amenities, while high-rise buildings emerged in neighbourhoods of low-rise houses, both becoming sources of urban conflict and housing activism after 2000.

The urban planning system reform stated key strategic elements such as the GUP (General Urban Plan) mandatory and valid for 10 years, for each administrative-territorial unit (ATU); the ZUP (Zoning Urban Plan) for ATU perimeters requiring modifications of land-use rules or change of their functions; and the DUP (Detailed Urban Plan) for changing the position of a construction within a parcel. Unfortunately, the drawing-up and approval of the first GUPs was a long-lasting action; in some cases, when approving the GUP, the reality of urban areas was already altered through the ZUP and DUP.

Disagreements between the rules established by the GUP and private investors' demands, some of them correct and necessary, others speculative and excessive, have been the primary source of land-use conflicts and civic engagement, fostering the inception of a specific regulatory framework regarding public consultation during the elaboration and approval of further spatial planning documentation.

The urban planning reform did not formulate a range of operational tools required for urban development as the right of pre-emption or real estate reservation, nor instruments for parcelling agricultural land that has become buildable and compulsory endowments before authorising construction, nor appropriate tools for urban regeneration. In their absence, conflicts, but also unsustainable urban projects, emerged in the centre, the peri-centre, and the peripheries.

In Bucharest, the first and only General Urban Plan was elaborated in 2000 under challenging conditions, using outdated cartographic data; 'pressure from contradictory development dynamics and strong private interests threatened, at times, its conclusion' [64] (p. 288). Also, in 2010, when the new General Urban Plan had to be adopted, the elaboration process was delayed. The current GUP has been extended numerous times, with the next update period being 2023.

On the basis of the GUP and according to the Urban Law No. 350/2001, the ZUPs and DUPs are designed at a smaller scale.

In order to support investments in urban area development, the law of urbanism allows modifications of the GUP through the ZUP and DUP, but the adjustment decisions are not taken and registered in the same institutions. Thus, the General Council of the Bucharest City Hall decides the modification of the GUP, as well as of the ZUPs, and DUPs in protected areas, while the Local Councils of the six sectors of Bucharest Municipality may decide to adjust the ZUPs and DUPs in the rest of the city and its new residential peripheries.

Unfortunately, in many cases, the modifications proposed by the private investors have either been undertaken by following inadequate urbanisation documentation (DUPs instead of ZUPs) or by addressing a local authority that did not have a mandate (Local Councils sectors instead of Bucharest City Hall). The lack of information, cooperation, and coordination in the decisions to modify the different urban territories has led in many cases to frequent urban and land-use conflicts, between both local authorities, as well as between authorities and citizens versus speculative investors who have not complied an authorised building regime.

- (c) Difficulties in the implementation of new master plans. The compromise of derogatory urbanism

In the circumstances of the aforementioned limitations regarding the constant updating of the urban planning documentation, a solution of compromise was practised, allowing the changes of the indicators and urban planning functions suggested by private investors, through derogatory regulations, 'derogations becoming law' (Minister statement, MDRAP, Laszlo Borbely, 2008). As such, 
although the situation was not admissible, from a civic perspective, until 2011, it was legal (a first measure to limit derogatory urbanism was imposed by OG 27/2008) [65].

Urban planning, based on exemptions from the law, has often been criticised by political opponents and considered to be an ultra-liberal urban policy instrument, as private investors can thus modify the GUP by initiating private ZUPs. 'The zoning ordinances conflict with investor's interest in obtaining the most profitable location for their new real estate projects' [66] (p. 170). According to a study on preserving urban heritage, some 200 to 300 ZUPs were approved per year, each with its exemptions from the GUP [67]. Specialists also criticised the effects of these derogations (2000-2011), as they produced territorial imbalances and an alteration of the urban image, aggressing protected areas and overburdening the infrastructure [68,69].

The numerous exemptions from the laws, associated with the lack of the 'vision of development' of the local public administration, generated a chaotic and unsustainable sprawl and gave priority to private investors' financial profits' rather than the public interest.

The 2000 GUP, extended many times and currently in the process of being updated, was criticised for the absence of vision and strategy and the lack of significant development directions. However, according to specialists, approval of several ZUPs widely discordant with the existing GUP did not necessarily suggest that 'exemptions established the rules' [70]. Even if the administration approved a few amendments to limit these practices and to reduce the spatial and visual effects of derogative urbanism, disallowed in 2011 by OUG 7/2011 [71], the dysfunctions raised by urban planning are still significant.

- (d) The changing role of public and private actors, new paradigms of planning and urban development

The multiplication of the actors was one of the most significant aspects of the new framework of post-socialist urban planning and development. Thus, in accordance with the changing economic and development paradigm, the public actors-initiators, financers, and decision-makers in all urban projects during the socialist period-will be substituted in specific segments of their activities by private investors, individuals, construction companies, banks and investment funds, real estate developers, civic associations, or residents.

In present circumstances, urban participatory planning ensures urban development by integrating and harmonising the opinions and perspectives of all interest groups.

As a result of the new logics of civic engagement, when authorities or private investors attempt to impose urban development projects without consulting the potentially concerned citizens, individuals and informal or organised groups engage in actions to protect the neighbourhood environment, heritage and local identity, legality, and general public interest.

Thus, in the last three decades, there have been 18 groups of civic initiative consisting of various experts (architects, sociologists, planners, legal practitioners, and lawyers), NGOs, and residents who gathered in a network called Rețeaua Civică București (Bucharest Civic Network).

Among them, a significant role in initiating actions against public authorities and speculative investors is played by Asociația Salvați Bucureștiul (Save the Bucharest Association). According to this association, most of the conflicts they reported were juridical, as the disputed projects benefited of several derogations from the legislation, and the building authorisation did not respect decisional transparency principles, the projects being of public interest.

\subsection{The Shifting Role of Public and Private Actors: Between Partnership and Conflict to Defend the Public Interest}

The Law No. 350/2001, on spatial planning and urbanism with subsequent amendments and completions, establishes the distribution of responsibilities and the general framework of cooperation between public and private actors in the planning and implementation of urban investments.

Public administration authorities are 'the managers and guarantors of this wealth, within the limits of their legal powers and, in order to ensure a balanced, coherent, and sustainable development of the national territory' and the local public administration authorities harmonise their land-use 
decisions based on the principles of decentralisation, local autonomy, and deconcentration of public services [63].

Therefore, according to the law [63], through public authorities, the state has the right and the duty to ensure, by urban planning and spatial planning activities, the conditions for sustainable development.

Moreover, fulfilling the role in the area of local planning and development relies not only on the cooperation between public actors, but also on the collaboration between public and private actors.

In practice, however, cooperation does not always work efficiently, owing to the lack of administrative and decision-making transparency (public actors), speculative economic motivations (private actors) or limited means of communication, and information of the population (organised civic actors and individual citizens).

Although the legal framework establishes rules and creates the general core of cooperation between public and private actors for sustainable urban development by defending the common interest, the reality has shown that numerous administrative dysfunctions or individual economic interests have modified this ideal frame. In some cases, the changing role of public and private actors regarding urban development and the inability of some of them to assume the new role established by law or the real estate market generated land-use conflicts.

- (a) The local public authorities have two essential responsibilities in close connection with the present research, both relevant sources of land-use conflict: to approve the urban planning documentation and grant building permits, and to control urban development processes, environment, heritage, and constructions. As mentioned above, in the case of Bucharest, there are two levels of administration (municipality and sector), sharing the responsibilities of approvals, authorisation, and control.

However, several issues left unaddressed by law made it possible for one of the authorities to issue administrative acts on behalf of the other, leading to legal conflicts with an impact on the whole city. The most relevant example is the Cathedral Plaza project, where the Sector 1 City Hall issued the building permit instead of Bucharest City Hall, even though it was under the administrative-territorial jurisdiction of the latter.

The new role of local public authorities, re-defined by the shift from absolute decision-making power to controlled decision-making and shared responsibility in urban development, is not entirely coherent, and frequently generates conflicts and reactions of other actors involved.

In this respect, one can mention the legal, but immoral decisions of the local councils, to approve urban development projects based on the principle of derogation, in the central areas (tower blocks raised on vacant parcels between houses and blocks erected in houses neighbourhood), as well as real-estate development projects (individual houses and residential complexes) in unorganised peripheral city areas, isolated from the city and without adequate urban amenities.

From this perspective, as a consequence of the inconsistency (who does what?) or the absence of legal provisions (parcelling rules and building permits), the legal decisions of the public authority generate conflicts and inevitably reactions of citizens and civic associations. Moreover, even today, informal parcelling and selling of residential plots can be approved before the developers complete the necessary building infrastructure, with the public authorities assuming this responsibility to be carried out later (according to Law of Housing No. 114/1996 [72], the period is usually inaccurate or not fulfilled by public authorities). Numerous civic initiatives are attempting to push the authorities to organise the necessary public infrastructure and facilities for access to the city, such as the Prelungirea Ghencea Initiative.

- (b) The economic actors (private investors and real-estate developers) have gradually expanded their activities since 1990, starting with individual investments, built by residents for their use, in the outskirts, or inside the city, followed, in 1995, by the first residential projects of the 'gated communities' type, raised outside the city (Pipera) and by large residential projects inside the city after 2000; however, numerous real estate investments spread out on the outskirts, beginning with 
2010, on vacant land or the site of the old industrial platforms, sequentially covering the empty land connecting Bucharest and the nearby localities (Chiajna, Popești-Leordeni, Bragadiru, Voluntari).

Private investors and developers took advantage of specific legal provisions to maximise their economic returns.

Most of the private projects that became the subject of land-use conflict were legal, but the technical-constructive solutions that were adopted favoured quantitative, not qualitative results (heights of buildings much taller than allowed by the rules of the area, extremely short distances between buildings, lack of parking areas for new buildings).

A series of well-known conflicts has targeted residential projects in which real estate developers did not comply with the urban planning indicators as mentioned in the building permit, nor did they complete all the public facilities mentioned in the visual documents preliminarily presented to clients; furthermore, they have eluded various advisory institutions requests to modify the project

- (c) Civic initiatives groups and residents. The emergence and increasing role of civic initiative groups are closely related to land-use conflicts rather than proactive actions to preserve or promote urban identity landmarks like neighbourhoods or parks. During the post-socialist period, the civic and associative attitude increased gradually, complementing the evolution of corresponding normative framework, as OG (Government Ordinance) No. 26/2000 on associations and foundations [73], or Law No. 350/2001 on spatial planning and urbanism [63], with provisions regarding the obligation to consult the population.

First actions were engaged mostly by individual residents when newly constructed houses in the neighbourhood affected their properties. Subsequently, several large-scale urban projects caused dissatisfaction, giving rise to the concern of the community; thus, the first initiative groups (informal) and even NGOs emerged that initiated collective actions to preserve the city, the environment, or historical monuments. Civic initiative groups and residents complained about the lack of transparency and legality of the actions of the public authorities, as well as against real estate developers, who have demolished heritage buildings without authorisation.

In the last decade, civic initiative groups (CIG) have developed and specialised in heritage, environment, or infrastructure, operating in associative networks at the city level (Asociația Salvați Bucurestiul, CeRe, Active Watch) or at the neighbourhood level, such as 'Prelungirea Ghencea' Initiative Group, 'Bucurestii Noi' Initiative Group, and Parcul Cișmigiu Initiative Group. Their actions concern, on the one hand, the 'supervision' of the legality of the activities of public authorities and real estate investors (transparency of decisions, legality of projects), and on the other, the information of citizens about the actions undertaken or planned by the former, as well as the provision of legal advice and procedures for residents who are potentially affected. It is worth mentioning the cooperation between local associative networks and professional organisations, such as the Order of Architects of Bucharest, to defend the right to a healthy and sustainable city in the domain of constructions and architecture and publishing the annual Report for Bucharest.

The actors of land-use conflicts may be different, but usually, these conflicts follow the triadic model, involving three parties and their contradictory interests: public authorities, private developers, and civic initiative groups and residents.

Deployment of land-use conflicts includes three stages: conflict emergence, conflict escalation, and conflict outcomes. The conflict emergence phase leads to the development of collective awareness from civic groups, the escalation phase entails the development of strategies and tactics, while the third phase sets the reactions of the public agencies to these strategies and tactics $[74,75]$. The emergence of a conflict 'follows an explicit commitment of the actors, by the implementation of a credible threat such as legal actions or mediatisation' [47] (p. 5).

Since 2009, to support citizen participation in the political processes, a resource centre called CeRe was set up. The number of civic initiative groups (GIC) has increased from 4 (2010) to 
18 groups in 2017, founding the Civic Network Bucharest (https://reteauacivica.ro/). The network was launched in April 2016, stating its mission 'to promote the participation of citizens in local public life, empowering politicians and public authority for an honest and responsible partnership between citizen, elected politician, and local public authority'.

\subsection{Participatory Planning and Civic Engagement in Bucharest City}

The urban planning process is a rational one, although specialists in the field often criticise the absence of a unitary vision of the parties involved. The city relies on a dynamic environment shaped by all actors and factors involved (citizens, local and central government, resources) and symbolic and cultural meanings.

There is a synergy between participatory planning and urban sustainability; participatory planning depends on governance schemes, as they are 'self-governance' and 'multi-level governance'. Planning scientists focused on integrative approaches in the strategic environmental assessment of spatial planning, sharing the concept of ecosystem services [76]. General scientific knowledge in the planning system extended the importance of the ecosystem as a specific reference. Particular attention was paid to the spatial dimension of ecosystem services as 'urban actors are more interested to know where to implement the plan than why' [77] (p. 1436).

Urban planning approaches need to be integrative in the negotiation and contestation of urban spaces $[78,79]$. Planning may coordinate public and private investment decisions; 'planners need to balance economic competitiveness, environmental sustainability, and social inclusion' [80] (p. 6). As well, development pressure was most intense around lakes and parks, with inadequate land zoning mostly threatening these amenities. Densification of urban areas has led to a loss of green spaces or 'urban greening' [81] and land reserve for housing constructions [82,83].

Moreover, it is necessary to integrate green infrastructure into what is meant by smart growth and the built environment [84]. Local planners face challenges and work in a situation of uncertainty, conflicting political goals, and significant imbalances of power [85].

In 2006, two articles of law No. 350/2001 [63] were modified to clarify and regulate the participation of the population in the activity of spatial planning and urban development; thus, the information of the population, the consultation of the population, and other forms of participation are mandatory. The information and consultation of the population are differentiated, depending on the size and importance of the documentation of spatial planning or urbanism (according to the procedures established by the Ministry of Public Works, Transport, and Housing).

The procedures were subsequently clarified by Government Ordinance No. 27/2008, stating that 'public consultation' is the process by which the central and local public authorities collect and consider the opinions of the public regarding the objectives of economic-social development, spatial planning, and the urban development of the localities. Order of the Minister of Regional Development and Public Administration No. 2701/2010 established the methodology for informing and consulting the public opinion regarding the elaboration or revision of the spatial planning and urbanisation plans [86].

Although initially, the methodology established that urban planning documentation and spatial planning approved without complying with the above-mentioned Order of the Minister 'are null and void' (Article 4), under the pressure of several mayors of expanding cities, this article was amended; therefore, not applying the procedure represents only an offence against local authorities.

Notwithstanding the reduced transparency and publicity of the local authorities regarding the consultation and information procedures, the process has improved significantly in the last decade, complementing the rising civic attitudes and the growing interest and public involvement in the problems of land-use and sustainable urban planning.

In line with the problems mentioned above, the strategic urban documents were not transparently elaborated on, and the General Urban Plan had not been updated until 2018, as planned. A lack of integrated studies that better assess the real development needs of the city, by involving more actively the public in planning processes, determined professionals to consider participatory urbanism to be 
unusable or worthless. The Order of Architects also suggests that, presently, the urbanism of the capital has converted into a 'collection' of litigious and illegal situations requiring well-planned corrections, which will help to solve the problems [87]. Meanwhile, the validity of the current GUP was extended up until 2023 [88].

If the effects of legislative decisions on land-use are generally known, the sides of activism, as well as their standing in local or central administration, are less recognised. The forms of activism are complex and can be practiced by various institutions, especially NGOs, private organisations, and various associations, whether they act to protect the rights of marginalised groups or to solve conflicts (preventing the evacuation of socio-economically vulnerable people), contributing to the affirmation or consolidation of some policies/regulations in the field of environmental conservation.

The first forms of public debate (conferences, workshops) and civic mobilisation coagulated within spatial planning departments of universities, and through NGOs, such as Asociația de Tranzitie Urbană (The Association for Urban Transition) and the Salvați Bucureștiul Association; the later criticised high-rise buildings constructed in protected areas and subsequently mobilised protest actions, gaining visibility in 2005-2006. Two emblematic cases have been the subject of civic mobilisation: the construction of high-rise buildings, in close proximity to historical monuments, one in a public park, next to 'Saint Joseph Cathedral', and another near 'Armenian Church'.

The Cathedral Plaza project was completed in 2010 and consisted of the construction of a $75 \mathrm{~m}$ high office building, with 19 floors and a surface of $23,000 \mathrm{~m}^{2}$, in the proximity of Saint Joseph Cathedral. The Roman Catholic Archdiocese of Bucharest contested the project, because the size of the office building massively affects the structural elements of this place of religious worship, belonging to the national heritage. The project has been litigated in the Romanian Courts, declared illegal in 2010 and ordered by the Court to be demolished in 2011. However, local authorities have no financial resources to implement the Court's decision and the building is currently still standing and unused.

Another project, Millennium Business Center, was controversial from the start, as the $74 \mathrm{~m}$ high building was attached to the parish house of the Armeneasca (Armenian) Church, affecting its structure. The litigation was dropped in 2003 after the developer paid damages of USD 790,000; in 2009, the building caught fire, and is presently standing in the same condition.

Following these, other civic groups, focussing on various issues such as street arts and housing evictions, cooperated and set up the platform for heritage protection Platforma pentru București (The Platform for Bucharest) [33].

The socio-economic and political context was not an obstacle and did not inhibit these types of civic or activist actions that emerged and expanded. The catalytic role of activism 'that centres on a visible and substantial change in social values, political debates and decision-makers, economic activities, or urban land-use patterns' [89] (p. 2) is also recognised.

Without intending to be placed into a 'responsible activist geographies, aiming to develop practices of social transformation rather than the production of knowledge or the solving of local problems' [90] (p. 10), the next section of the article highlights the problems of spatial planning and land-use conflict from the perspective of experts and civic action groups.

The term land-use conflict is insufficiently defined in the literature, but considered from a spatial perspective, 'occurs whenever land-use stakeholders (conflict parties) have incompatible interests related to certain land-use units (geographical component)' [7] (p. 149). In this article, we use the meaning of land-use conflict proposed by the authors mentioned above, because the conflicts arising from issues related to private or public property have determinants and produce effects at a territorial level, and thus have a geographical dimension.

Land-use conflicts are the most representative at a spatial level. Conflicts can result from projects of construction, implementation, or extension of activity; projects of development or access modification; or the emission of adverse effects [47]. In Bucharest, changes in land-use after 1990, mainly the extension of the built area over green spaces, forests, and industrial areas, can be sources of land-use conflicts. 
The map shows those areas where the destination of some land has been significantly changed, creating the context for potential conflicts to arise (Figure 1).

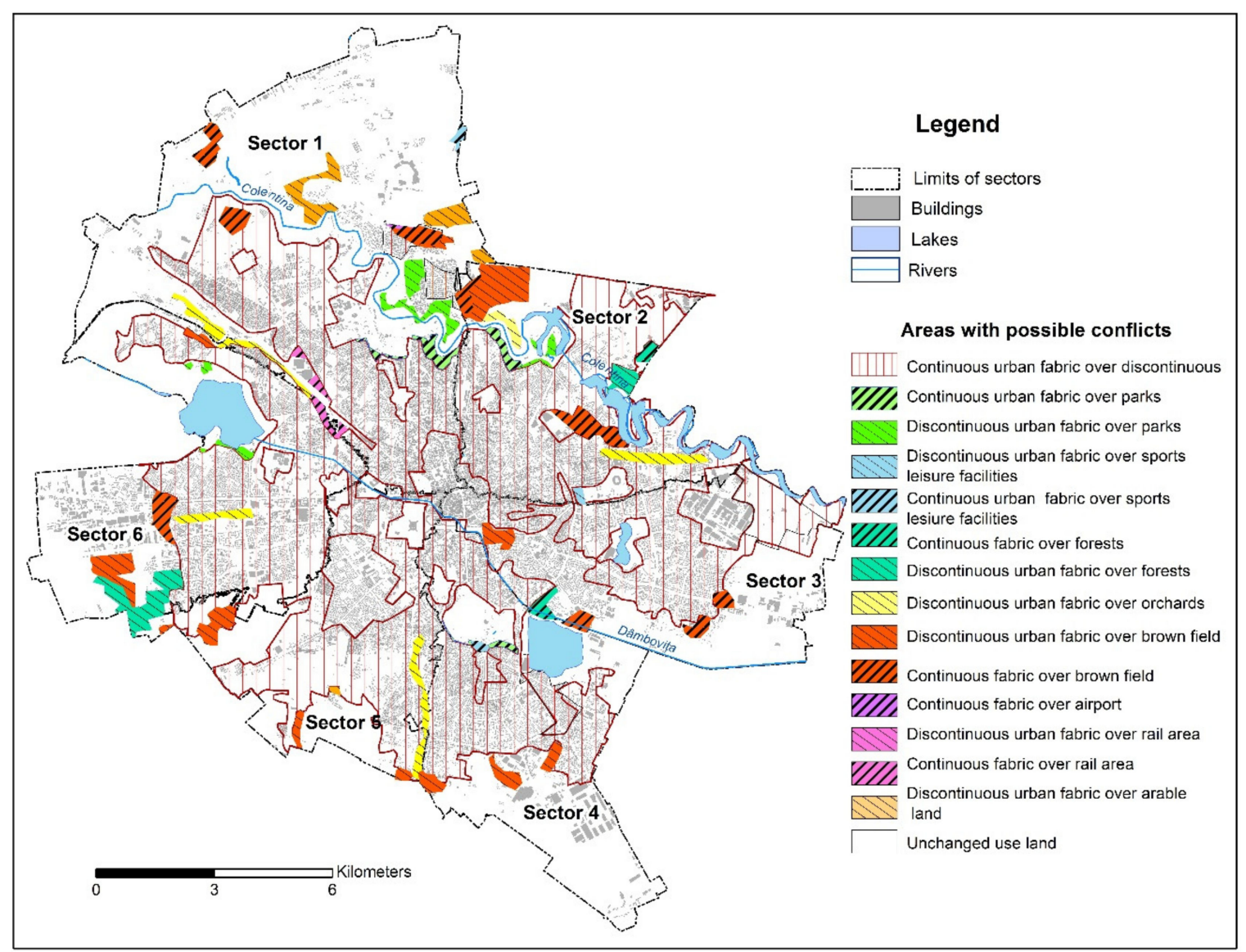

Figure 1. Changes in land-use $(1990,2012,2018)$ : areas of possible conflicts. Data source: Corine Land Cover (CLC) 1990, 2012, and 2018.

Our findings show that land-use conflicts occur mostly in central areas of the city and the urban fringe area, along with the new residential developments in the outskirts (Figure 2). Central areas of the city mainly represent a challenge for sustainable development and urban regeneration, owing to location and functional transport connectivity. There are areas of high urban readability, legibility, and livability [91]. In Bucharest, the central area is predominantly residential, with $65 \%$ of its surface holding the status of a 'built protected area', which also includes 2036 historical buildings from a total of 2269 monuments registered in Bucharest. The conflicts occurring in the central area are not necessarily related to the changes in the use of land, but to the non-compliance of new construction projects with the urban indicators established by the GUP, or with the rules derived from the protection regime of historical monuments or protected zones.

Thus, through the mentioned derogation procedures, legal, but often speculative, the conflicts were generated by newly erected buildings, larger and higher than neighbouring ones, or which, through their location, had adverse effects on the living environment.

On the other hand, new residential developments in the outskirts are undergoing a high densification process. They give specific geographical meanings to urban housing, with the residents relating differently to the built space, and to the proximity. to the green spaces and amenities, where the neighbourhood is the essential tier. A high densification of urban housing substantially changes the specificity of these areas, altering the neighbourhood character, which should be precisely recognised and preserved by all the actors involved in urban planning; furthermore, participatory planning should be the instrument throughout the characteristics of the neighbourhood, and its identity is valued. 


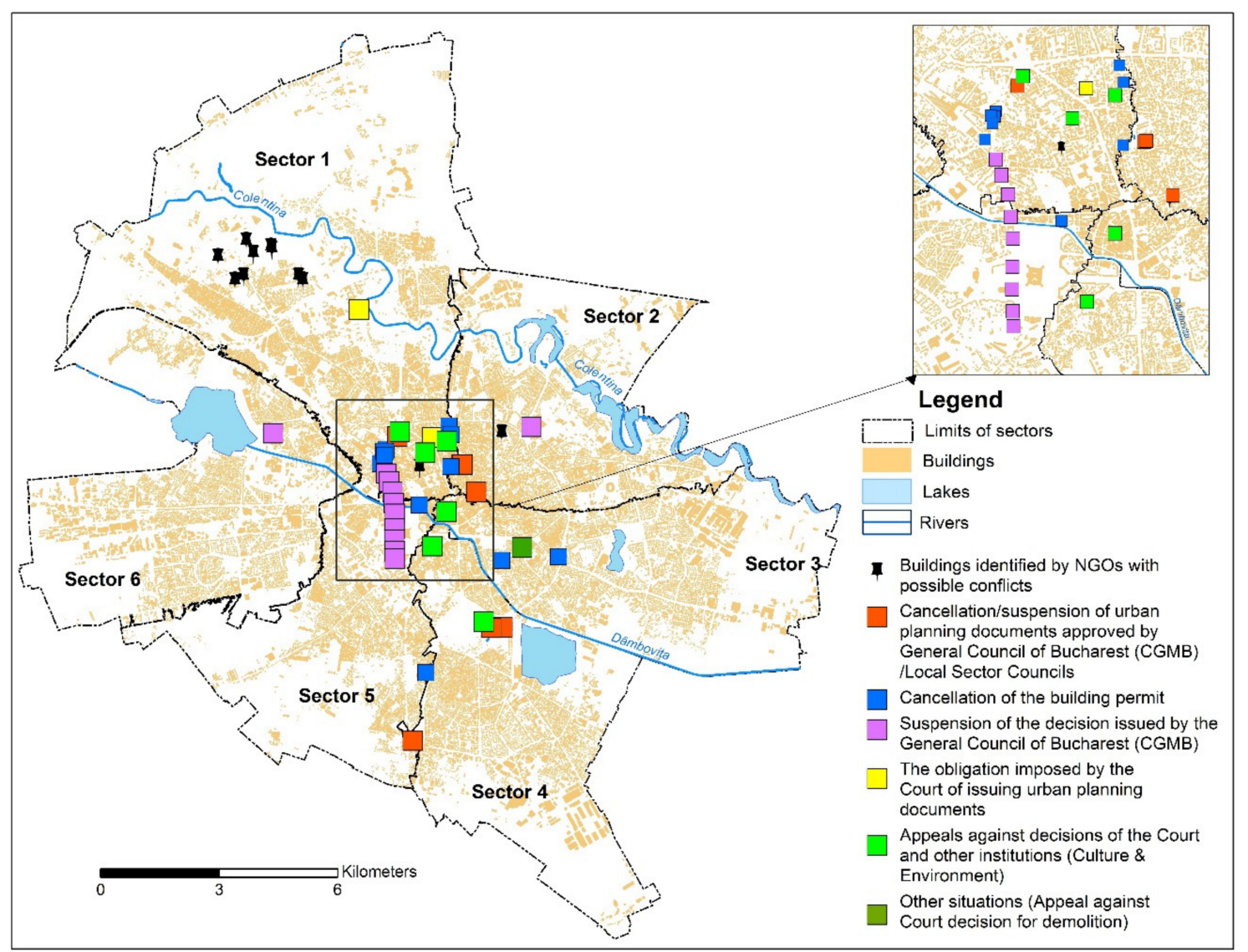

Figure 2. On-going or solved conflict cases. Data Source: Asociația Salvati Bucurestiul, 2019 https: //www.salvatibucurestiul.ro/.

The housing activist initiatives and land-use conflicts, as constitutive parts and attributes of the social movement process, can be seen from a constructivist and interpretive perspective through which events, activities, and actors are embedded with contestable and negotiated meanings. All the information and texts specific to this phenomenon-press release, interviews with activists and planners, websites, slogans-are composed in a certain way to convey messages with dominant meanings and resonance. Frame analysis provides interesting insights in this situation. The frames, as essential conveyors of meanings, contribute to the interpretation and problematisation, functioning similar to a picture frame that highlights things and shades others [92]. Our findings revealed that ideative patterns throughout the issue of land-use conflict are understood and interpreted by the public.

The frame 'urban chaos' dominated the public discourse of planning professionals and activists, the content of news, and social media information.

It is highlighted, mediated, and exposed during public events or protests that 'land-use conflict' is identified as an issue, while the primary sources of land-use conflicts relied on post-socialist transformations, derogatory urbanism, and weakness of public administration; the solutions suggested better regulation, law information, and court resolutions.

Sources of land-use conflicts are diverse, with disputes arising from the deterioration or destruction of constructions or public infrastructure, the expansion of residential developments over litigious land, the changes of construction projects in a non-transparent way, access issues to different amenities (parks, green spaces), and land degradation (Table 2). 
Table 2. Types and forms of conflicts (authors findings).

\begin{tabular}{|c|c|c|c|}
\hline $\begin{array}{l}\text { Nature of Conflict } \\
\text { Context and Causes }\end{array}$ & Parties/Stakeholders & Conflict Issues & The Current Trend in the Conflict \\
\hline Structural/proximate/triggering & Interest/goals/relationship & Manifestation/stage & Mediation/resolution \\
\hline $\begin{array}{l}\text { Confused urban legislation } \\
\text { Increased urban densification } \\
\text { Promotion of neoliberal urban policies } \\
\text { Approval and proliferation of ZUPs in } \\
\text { private interest: } 200-300 \text { ZUPs/year } \\
\text { (2003-2011) } \\
\end{array}$ & $\begin{array}{l}\text { Private developers } \\
\text { Municipality } \\
\text { NGOs and residents }\end{array}$ & $\begin{array}{c}\text { Network of civic groups beginning } \\
\text { in } 2012 \\
\text { Environmental protests Uniti Salvăm! } \\
\text { (United we save!) } \\
\text { The platform for heritage conservation } \\
\text { 'Platform for Bucharest' }\end{array}$ & $\begin{array}{c}\text { Resolution by lawsuits (small-scale } \\
\text { residential projects) } \\
164 \text { resolutions by lawsuits according to } \\
\text { Salvați Bucurestiul Association }\end{array}$ \\
\hline $\begin{array}{l}\text { Urban regeneration in protected areas } \\
\text { (central areas) }\end{array}$ & $\begin{array}{l}\text { Millennium Building Development vs. } \\
\text { Roman Catholic Archdiocese (ARCB)/ } \\
\text { The Municipality (dispute over } 15 \text { years) } \\
\text { NGO network Uniți Salvăm! }\end{array}$ & $\begin{array}{l}\text { Office tower Cathedral Plaza, } 75 \text { m high } \\
\text { Environmental protests Uniti Salvăm! } \\
\text { The platform for heritage conservation } \\
\text { 'Platform for Bucharest' }\end{array}$ & Demolition proposal by final court decision \\
\hline $\begin{array}{l}\text { Urban regeneration in protected areas } \\
\text { (central areas) }\end{array}$ & $\begin{array}{l}\text { Degi Aberdeen (developer) vs. } \\
\text { Armenian Church }\end{array}$ & $\begin{array}{l}\text { Office tower Millennium Business Centre, } \\
74 \mathrm{~m} \text { high, near Armenian Church }\end{array}$ & $\begin{array}{c}\text { Dispute resolved in } 2003 \\
\text { Payment of damages of } \$ 790,000\end{array}$ \\
\hline Small-scale residential projects & $\begin{array}{l}\text { Municipality } \\
\text { Private developers } \\
\text { Residents }\end{array}$ & $\begin{array}{l}\text { Issues in the approval process } \\
\text { Appeal for building permits } \\
\text { Local protests through Bucharest } \\
\text { Civic Network }\end{array}$ & $\begin{array}{l}\text { Court action. } \\
\text { Demolition of one small-scale residential } \\
\text { project (with the expenses of the private } \\
\text { developer, Giurgiului Street case) }\end{array}$ \\
\hline Park and green spaces & $\begin{array}{c}\text { Public authorities/Municipality } \\
\text { Residents }\end{array}$ & $\begin{array}{l}\text { Land in dispute (Bordei Park) } \\
\text { Expropriations of green spaces }\end{array}$ & $\begin{array}{c}\text { Court action } \\
\text { Actions in pronouncement }\end{array}$ \\
\hline
\end{tabular}


As the civic mobilisation and protests initially targeted heritage conservation, the frame analysis looks at how the land-use conflicts as a topic are framed by different actors in heritage and housing disputes.

Our findings suggest that there are three core framing tasks: the diagnosis of heritage buildings, many of them requiring costly interventions (diagnostic framing); the solutions proposed to the problems identified (prognostic framing); and mobilisation and participation actions (motivational framing).

Using the typology of Shmueli [43], we can point out briefly that the reasons leading to conflicts are different and rely mostly on changes that the actors involved perceived as being contrary to their interests or wishes (Table 3).

Table 3. Patrimonial and residential housing dispute: identity values versus substance frames (authors findings).

\begin{tabular}{|c|c|c|c|c|}
\hline \multirow{2}{*}{ Stakeholder } & \multirow{2}{*}{ Identity/Values } & \multicolumn{3}{|c|}{ Substance } \\
\hline & & Aspirations & Outcomes & Issues \\
\hline $\begin{array}{l}\text { Civic groups } \\
\text { and residents }\end{array}$ & $\begin{array}{c}\text { Orientation } \\
\text { justice and rights }\end{array}$ & $\begin{array}{l}\text { Preservation of patrimonial } \\
\text { heritage of the city: Project } \\
\text { 'Case care plâng' } \\
\text { (Crying houses) }\end{array}$ & $\begin{array}{c}\text { Monitoring and } \\
\text { enforcement } \\
\text { Monitoring of } \\
\text { patrimonial housing }\end{array}$ & $\begin{array}{l}\text { Architectural quality } \\
\text { objectives } \\
\text { Enforcement mechanism } \\
\text { and who is responsible }\end{array}$ \\
\hline $\begin{array}{l}\text { Government } \\
\text { authorities }\end{array}$ & Public interest & $\begin{array}{l}\text { Renovation and restoration } \\
\text { proposal }\end{array}$ & & $\begin{array}{l}\text { Architectural quality } \\
\text { objectives }\end{array}$ \\
\hline $\begin{array}{c}\text { Private } \\
\text { developers }\end{array}$ & $\begin{array}{l}\text { Economic } \\
\text { orientation }\end{array}$ & $\begin{array}{l}\text { Find best locations } \\
\text { The benefit of land reserve } \\
\text { Raising the standard of living }\end{array}$ & $\begin{array}{l}\text { Improving the living } \\
\text { environment } \\
\text { Brand image }\end{array}$ & $\begin{array}{c}\text { Risks of high } \\
\text { densification } \\
\text { Deal of local protests }\end{array}$ \\
\hline
\end{tabular}

The frame is based on the following elements: identity and values, phrasing, substance, process, and characterisation. The frame's identity and values involve elements related to the decision-making process; how the parties involved relate to the fundamental values of society organisation; phrasing frames involving the modalities and techniques of conflict communication (win/lose, win/win, complete story); and substance frames referring to situations in which the parties to the conflict relate to the issues concerned: 'aspirations: general hopes for fulfilment of vital interests; issues: the perceived bones of contention; outcomes: specific positions or desired solutions to the conflict at hand' [43] (p. 2051).

\subsection{Housing Activism, Public Administration, Contested Meanings, Practices, and Discourses}

Engagement of civic initiatives groups in housing activism, the changing role of actors, and paradigm in spatial planning produced discursive articulations of the relationships between spaces, actors, and societies. Driving forces can change; power relations between actors are interchangeable, as are their discursive practices. The discursive formations that transmit and produce power relations are potentially reversible. Discourse is not a simple text; it means ways of thinking and actions; it is a 'network of signs, symbols, and practices' [93] (p. 11).

Discourse analysis is a critical method and seeks to describe episodes and practices.

In the case of Bucharest, the emerging themes are divided and selected as discursive statements and practices in two categories: the first, which positions the crisis of local authority and urban chaos; and the second, which includes city recovery and participatory planning, as a core for urban and sustainable development.

3.4.1. 'Urban chaos', ‘Weak Local Governance', 'Lack of Urban Identity and Sense of Place': Key Issues in the Views of Experts

Experts pointed out that the liberalisation of the construction and real estate market based on an outdated legislative framework and derogatory regulations generated significant problems in city planning and had a de facto crucial catalytic role in the emergence of potential land-use conflicts. The urban evolution was dramatically altered under pressure from the private developers; they are, 
actually, the main beneficiaries of the derogatory urbanism provisions, which generated, over time, the 'urban chaos', easily recognisable visually through numerous construction projects, varying in size, height, and architectural style.

Therefore, the modernisation of the city was not carried out according to the principles of sustainable development; concerning this issue, the experts have contradictory reactions. Some of the experts adopted a more sceptical attitude, as there would be no technical solutions for the current urban challenges of the city, principally owing to the lack of updated GUPs; new General Urban Plan proposals were blocked many times, favouring the derogatory urbanism, alongside outdated plans.

Bucharest City's situation is not a singular one; in many others localities in Romania, cadastral works are not completed yet, and general plans have not been revisited over the years (in 2012, 42\% of localities have outdated urban plans, out of which only $25 \%$ had extended their validity terms).

The surface area of the city was 24,190 ha according to National Institute of Statistics (2016), while the GUP covers only 22,800 ha; thus, over 1390 ha is not registered in the City Hall documents. Relatedly, newspapers' front pages and news sites often addressed aspects of Bucharest city reality: 'Bucharest lost, in documents, almost 1,000 hectares from its surface' [România Liberă, 3 May 2018]; 'Bucharest, seven cities in one. The urban chaos of the capital is the result of the interests (differential) of the sectors town halls' [Active news, 25 October 2016]; 'Where there is no strategy, is congestion. Urban chaos in the absence of development plans for Bucharest'[TVR News, 11 June 2017]; 'The Bucharest residents of Floreasca protest against the urban chaos of the neighbourhood' [România Curată, 30 March 2016]; 'A capital without borders. Bucharest develops chaotic' [Digi 24 News, 12 June 2015].

Other structural problems revealed the crisis of high professionals in the field; the lack of architects in the town halls; the absence of a dialogue between professional organisations (RUR, OAR, UAR), experts, universities, and local authorities; as well as the reduced efficiency of the inspections carried out by the State Inspectorate for Construction (SIC). The State Inspectorate for Construction is the authority that verifies the correctness of the building permits, and it holds the power to stop the construction works when they are not performed based on legal authorisation or give sanctions if the construction does not comply with the authorisation according to Law no. 10/1995 [62].

Other experts are more optimistic, being in favour of identifying sustainable solutions to urban and economic growth and urban regeneration, rather than implanting random blocks and office towers in the urban tissue dating from the 19th or early 20th century. Residential developments are mostly private initiatives, and the local administration has no capacities to control the development projects (no longer sustainable), only endorse them.

Regarding the high densification process, the experts mentioned that the most frequent cases occur, either in several sections of the central area or in the neighbourhoods of the peri-central and peripheral area, where four-floor-block types were built, with the percentage of occupancy of the land surpassing $80 \%$. The infrastructure is inadequate, and the existing facilities are overloaded.

Undoubtedly, many residential projects also produced socio-spatial effects, such as altering the sense of the place, changing the character of the neighbourhood, affecting the living environment through high densification of constructions, reduction of the green spaces, high pollution, traffic noise, and the absence of residential parking.

In the opinion of the experts, when developing new residential projects, less attention is paid to preserving the sense of the place or neighbourhood identity; conserving the identity of the neighbourhoods could only be found in some guides and rules, and relates mostly to the central areas of the city.

Also, the question arose as to whether, at the cognitive level (symbolic meanings), the image of neighbourhoods, with heritage value, is affected by an increased level of housing development in restrictive area zoning. Some projects are considered controversial, as they are built in protected areas, with a specific identity, for example, the Cotroceni neighbourhood, Vatra Luminoasă, Bucureștii Noi. However, this sense of place is at risk of being lost. 
In the peripheral and urban fringe areas, the problem of proximity and the inability of the public administration to solve problems related to urban facilities have determined several civic initiative groups (CIG) to act together in different areas of the city, such as Prelungirea Ghencea, Domnești, Tei.

\section{5. 'Fight for the City and the Neighbourhood': Narrative Discourse and Practices of NGOs' Representatives}

Civic engagement or civic participation represents the expression of the interests and aspirations of citizens organised in different forms, to work collectively to achieve different common goals. Civic initiative groups play an essential role in promoting ideas or changes of a political or economic nature, campaigning to prevent or mitigate long-term negative consequences on individuals, groups, or areas, mobilising people for common concerns. They belong to a physical space and place, emerging in different neighbourhoods of the city, but also build virtual communities imposing particular models of interaction through social media and online spaces.

Therefore, 'activism is not only a social phenomenon, but it is also a spatial one. Spatial scale is a process, as well as a characteristic. In other words, space and location are not static containers of activism, but rather, they are dynamic features that interact in important ways to enable or obstruct activist efforts' [89] (p. 5). Contested spaces are not only geographical and physical spaces; they are also spaces of discursive practices. In this sense, the discourse understood in terms of power 'encompasses ways of thinking and actions' [94] (p. 303).

Therefore, the question arises on how discourses, in the Foucauldian sense, are formed. We are interested in discourse formation, as the active-reactive narrative oppositions, domination and resistance, and inclusion and exclusion are highlighted in the discourse. Emphasis is given to the dynamic mechanism of discursive formation that entails the power relationship between discursive statements.

Discursive statements could provide many perspectives/directions for understanding the nature of the relationships between the parties in conflict. Also, the key messages through which these groups identify, helping them to build spaces, places, and communities, are essential. The texts on the own websites of the civic initiative groups (GIC) involved were retrieved, translated, and organised.

Using Voyant Tools [52], we performed a KWIC (keyword in context) analysis that helped us to analyse particular keywords and their local meanings in relation to a fixed number of words (Supplementary file).

The text corpus included 1878 total words and 589 unique words, with a vocabulary density of 0.314; an average words per sentence of 47.6 ; and the following occurrences: group (22), community (19), neighbourhood (19), public (17), and authorities (14).

The findings suggested that the group-community-neighbourhood triad is the strong message of the 18 groups involved in participatory planning. Local civic initiative groups emerged in all administrative units of the city, but are more numerous in Sector 1, considered to be grassroots projects; their names usually relate to the theme of public interest launched (e.g., Floreasca Civică, Prelungirea Ghencea, Lacul Tei, ÎnCotroceni, Luptăm pentru Aleea Lunguletu/We fight for Lungulețu Aleea, Salvati Parcul Tineretului /Save Tineretului Park, Bucurestii Noi, Floreasca).

These associations emerged mainly in the neighbourhoods with protected, heritage value buildings. The associations Salvați Cartierele Dămăroaia (Save Dămăroaia Neighbourhood) and Bucureștii Noi claim that 200 buildings, in an area of 10 square $\mathrm{km}$, would not comply with either the legal conditions concerning the building permits or the administrative documents for land tabulation.

'Fight for the city' is the leitmotif of the actions and programmes of these groups. Action is an exercise of power. 'Community' and 'neighbourhood' represent spatial markers, which encompass spatial meanings, hence the role that names play in the logic of belonging to a territory.

The neighbourhood functions as a geographical place, which can be socially constructed, but is also subject of meanings, which the groups are trying to promote. This may partially explain the reason these groups preserve and promote the names of the places, in support of their identification with the neighbourhood and community. 
The groups adopted the names of the neighbourhoods and the community, as place names have a spatial and symbolic background. Language, geography, and place names are linked to the question of power, culture, location, and identity [95-97].

Binary oppositions, 'they' and 'we', frequently occur in the discourse, and civic groups position them on what should be done/what is done. Active-reactive narrative oppositions, domination and resistance, and inclusion and exclusion are frequent in their discourses.

The discourse extends into realms of ideology, strategy, language, and practice, and is shaped by the relationships between power and knowledge [44]. The power is not understood from the top down, power is everywhere (rule of immanence, according to Foucault), and can also be found in the relationships between the actors in planning (architects, planners, citizens, public authority, interest groups). The conflicts and tensions are rather seen as debates and arguments.

Proximity, neighbourhood, and community represent core values for representatives of civic groups; the lack of basic amenities visibly alters the configuration of new residential developments and projects.

In their views, the neighbourhoods are 'socially constructed' spaces; they are arenas of discursive practices; they are disputed, negotiated, and constructed through power struggle and interests [98].

The perspectives of the CIG representatives on the 'urban chaos' converged to 'urban development that generates imbalances', resulting in 'overcrowding of the existing neighbourhoods'; 'development of the new areas, without amenities or public services'; or 'aggression of the green spaces between the blocks' (Supplementary File).

The discourse often takes the form of a social act, polarised around the absence of basic amenities, green spaces, and parking lots. It is also contextually situated, and verbal expressions with a slight tendency to hyperbolise arise; this can be interpreted, depending on the context, as tokens of sensitisation of public opinion and residents, or levers to highlight the non-compliant situations more easily (e.g., 'overcrowding', 'aggression', 'illegal', 'non-compliance', 'offence').

Land-use conflicts are understood and interpreted in a legal-normative-applicative logic, as a rational form of knowledge and knowledge production, often disputed. Who participates in the elaboration of the urban documentation? Who expertises these documents? For whose benefit?

In this wake of knowledge production, tendencies or forms of manifestations of institutionalised legalism are also recognised, being generated by ambiguous regulations or law deficiencies. Therefore, the following paradox arises: breaching the law, if possible, or law enforcement, by derogation, when $20 \%$ changes are permitted, both subsequently altering the local context.

The representatives of the civic groups consider that there are several situations of violations of the law: 'non-compliance of building permits with official zoning regulations', 'the lack of mechanisms to control construction activities', and 'lack of legislative support' or 'unclear legislation and interpreting regulations'.

The legislative amendments are not sufficient and failed to correct existing dysfunctions, as the law still maintains some 'wrong elements'.

The legal-normative component thus becomes the indisputable support of discursive statements' formation. The source of conflict is generated, on the one hand, by the production/knowledge ratio (urban documentation, ZUP), and by the production of the built space (parcel/plots) on the other hand.

Civic initiative groups advocate for strengthening the respect of the rules of law when developing new residential projects; for preserving green spaces and other amenities; and for promoting advocacy guides, in print and digital format. Power relations within these groups construct through targeted campaigns and engagement in lobbying activities (although legal regulation of these matters does not exist so far); they organise formal or informal meetings with the decision-makers and advocate for the creation of working groups, made up of stakeholders and representatives of the public administration, to solve specific problems, thus facilitating active participation of citizens in the decision-making process. 
Residents affiliated to a civic association could have several benefits; associations facilitate the dialogue between residents and local authorities, provide residents with legal support and full information to solve bureaucratic problems, suggest tariff reductions for DUPs in new residential areas and individual house projects, and build and sustain community networks; thus, through these groups, residents gain the skills to advocate and lobby for themselves; they have higher power and strength to influence public decisions, as well as a louder voice that cannot be ignored.

Usually, these groups are higher profile, and they are critical of local authorities and urban planners. Considerable emphasis was placed on several issues, mainly addressing public participation and urban sustainability. Sensitive topics often arise in their discourse: 'the connivance between the administrative authority and other interests', 'the urban planning documentation non-compliance with the legislation', 'the problems of the building permits', 'the lack of responsibility in the field of construction work control' and 'release of the reception reports of the finished buildings', and 'changing the destination of green spaces through urban planning documentation'.

The civic initiative groups have adopted various strategies to raise awareness of the residents or local community in order to preserve the identity of the neighbourhoods and, implicitly, to be actively involved in the participatory planning process, from collecting signatures, flyers, and online petitions to organising protests and public debates.

The leader of the NGO Salvati Bucurestiul admits that the most effective strategies and actions are the legally registered associations and civil actions in court (conjugated or separately). Generally, local public authorities are constrained by actions that impact many people through the media. Unfortunately, the press is no longer interested in these topics and does not sufficiently explain them, and the subject of 'urbanism' (derogations, illegality related to urban development) is already worn out. Petitions and protests are no longer effective unless they reach many people, which is rare today. Establishing associations and actions in court generates concern among civil servants, who may commit law breaches.

Discourse encompasses models of communicative events. Some experts advocated for the reform of the institutions, while others favoured more involvement and participation of citizens. There are cases in which the parties involved in the conflict have different opinions; the associations accuse the authorities, while the responsible local authorities sustain their legality. The struggle for urban sustainable development has often opposed the partisans of preserving the old city and those who are keen on new developments, those who have supported the renovation of the city centre versus those who have developed dwellings in the urban fringe, and between activists who support compliance with planning rules and the promoters of the urban derogations. Housing activism initiatives are diverse in forms and manifestations and could be key in the regional development and governance of local activities.

\section{Conclusions}

The adoption of neoliberal urban policies after 1990 has significantly changed the logic of urban planning, but has also led to environmental conflicts emerging from abusive land-use.

The absence of cohesive city development plans and inadequate planning strategies produced real long-term consequences on the urban development and the quality of life of the inhabitants.

The article presented sequences housing activism initiatives and land-use conflicts for the case of Bucharest City, drawn on socio-spatial reality and empirical insights into the emerging process of community engagement in urban development issues, the neighbourhood protection movement, and the power relationships between the actors involved.

Exploring housing activism as an emerging phenomenon; we have attempted in this paper to identify the source and type of land-use conflicts that are highly interrelated with the production of meanings.

Through frame and discourse analysis, we look at how the fight for the city discourse and rationale of action were constituted in the corpus of data. Land-use conflict and urban chaos are nodal 
points of a discourse being filled with meanings via recurrent words or expressions: 'community and neighbourhood', 'identity and belonging', 'illegal', 'compliance', and 'law enforcement'.

In relation to urban evolution, as well as legislation in the field of urbanism, housing activism led to the development of non-governmental associations and civic action platforms (reactive and proactive) aimed at involving the citizens in the transformation of their neighbourhoods, increasing their engagement in the analysis and implementation of the urban planning projects proposed by authorities, developers, or other investors.

These housing activism initiatives, through civic initiative groups, gained popularity through their actions and established various systems of interaction between the actors involved. The topic addressed is complex and would have required ethnographic research and fieldwork, carried out over a more extended period. Therefore, as limits of the study, one can mention that we were not able to expose enough the value of the interactions of all the actors involved: on the one hand, the representatives of the municipality, as decision-makers, who are reluctant to give interviews; and on the other hand, the residents, who are dissatisfied with the projects developed in their immediate vicinity.

Actors play a decisive role in participatory planning, a process with inequalities in expertise and funding, with different imbalances of power. Actors compete on spatial resources and construct concepts of environmental issues, conflicts, and tensions, embodied in discourses, reproduced and transformed into social meanings.

Also, from this perspective, we have not offered a suggestive and holistic interpretation of the land-use conflict, as the actors attempt to position themselves in relationships with each other, and the process of land-use conflict, as a social construct, is related to the subjectivity shaped by the experience of residents involved.

The activity of civic initiative groups is recognised as being positive by the experts; some of them suggested online petitions, flyers, and website design as effective strategies, while others recommended more radical measures, such as protests, lawsuits, or actions to demolish non-compliant buildings.

Overall, these civic actions expand and become more visible, but they lack the critical and objective support of experts and professionals in the field. A critical perspective, of course, cannot encompass the circumstances and effects of post-socialist transformations only to legitimise progressive ideas, of in situ adopting the ideal model of the Western city, without urban dysfunctions and planned according to the norms. A dialogue with the specialists in the field is essential as the strategies proposed by the civic groups are useful, but they do not respond to the current issues. Experts advocate for constructive actions, education and training, and awareness of all stakeholders (investors and local community) of whatever the built environment means.

Local community awareness and residents' engagement in preserving the identity of the neighbourhoods, as well as their participation in the planning processes, remain sensitive and elusive.

Supplementary Materials: The following are available online at http://www.mdpi.com/2071-1050/11/22/6211/s1, Figure S1: KWIC with voyant tools. Results; Quotes: Quotes and excerpts text from interviews (experts and NGOs representatives).

Author Contributions: All authors contributed equally to this paper.

Funding: This research is partially funded by Faculty of Geography, University of Bucharest.

Acknowledgments: The authors acknowledge all the experts in the field who supported our research; we express our gratitude to Nicușor Dan, leader of NGOs Asociația Salvați Bucureștiul, for his willingness to support our efforts.

Conflicts of Interest: The authors declare no conflict of interest.

\section{References}

1. Duke, J. Institutions and land-use conflicts: Harm, dispute processing, and transactions. J. Econ. Issues 2004, 38, 227-252. [CrossRef]

2. Coppens, T. Conflict and Conflict Management in Strategic Urban Projects. Ph.D. Thesis, Katholieke Universiteit Leuven, Groep Wetenschap \& Technologie, Arenberg Doctoraatsschool, Heverlee, Belgium, 2011. 
3. Van Dijk, T.; van der Wulp, N. Not in my open space: Anatomy of neighborhood activism in defense of land use conversion. Landsc. Urban Plan. 2010, 96, 19-28. [CrossRef]

4. Campbell, S. Green cities, growing cities, just cities? Urban planning and the contradictions of sustainable development. J. Am. Plan. Assoc. 1996, 62, 296-312. [CrossRef]

5. Humphreys, J.S.; Walmsley, D.J. Locational conflict in metropolitan areas: Melbourne and Sydney, 1989. Aust. Geogr. Stud. 1991, 29, 313-328. [CrossRef]

6. Torre, A.; Aznar, O.; Bonin, M.; Caron, A.; Chia, E.; Galman, M.; Lefranc, C.; Melot, R.; Guerin, M.; Jeanneaux, P.; et al. Conflits et tensions autour des usages de l'espace dans les territoires ruraux et périurbains. Le cas de six zones géographiques françaises. Rev. Écon. Rég. Urban 2006, 3, 411-450. [CrossRef]

7. Von der Dunk, A.; Regamey-Gret, A.; Dalang, T.; Hersperger, A.M. Defining a typology of peri-urban land-use conflicts-A case study from Switzerland. Landsc. Urban Plan. 2011, 101, 149-156. [CrossRef]

8. Tappert, S.; Klöti, T.; Drilling, M. Contested urban green spaces in the compact city: The (re-) negociation of urban gardening in Swiss cities. Landsc. Urban Plan. 2018, 170, 69-78. [CrossRef]

9. Zukin, S. Changing Landscapes of Power: Opulence and the Urge for Authenticity. Int. J. Urb. Reg. Res. 2009, 33, 543-553. [CrossRef]

10. Elkington, S.; Gammon, S. Reading Landscapes: Articulating a Non-Essentialist Representation of Space, Place and Identity in Leisure. In Landscapes of Leisure: Space, Place and Identities; Elkington, S., Gammon, S., Eds.; Palgrave, Macmillan: London, UK, 2015; pp. 1-7.

11. Essex, S.; Brown, G. The emergence of post-suburban landscapes on the North Coast of New South Wales: A case study of contested space. Int. J. Urban Reg. Res. 2002, 21, 259-287. [CrossRef]

12. Jensen, D.; Baird, T.; Blank, G. New landscapes of conflict: Land-use competition at the urban-rural fringe. Landsc. Res. 2018, 44, 418-429. [CrossRef]

13. Goetz, E. Resistance to social housing transformation. Cities 2016, 57, 1-5. [CrossRef]

14. McAvoy, G. Controlling Technocracy: Citizen Rationality and the NIMBY Syndrome; Georgetown University Press: Washington, DC, USA, 1999.

15. Bedford, T.; Clark, J.; Harrison, C. Limits to new public participation practices in local land use planning. Town Plan. Rev. 2002, 73, 311-331. [CrossRef]

16. White, S.S. Public participation and organisational change in Wisconsin land use management. Land Use Policy 2001, 18, 341-350. [CrossRef]

17. Pacione, M. The power of public participation in local planning in Scotland: The case of conflict over residential development in the Metropolitan Green Belt. GeoJournal 2014, 79, 31-57. [CrossRef]

18. Załęczna, M. Public participation in land use planning and the building of a civil society. Real Estate Manag. Valuat. 2018, 26, 23-32. [CrossRef]

19. Offe, C. Capitalism by Democratic Design? Democratic Theory Facing the Triple Transition in East Central Europe. In Varities of Transition. The East European and East German Experience; Offe, C., Ed.; The MIT Press: Cambridge, MA, USA, 1997; pp. 29-49.

20. Kuzio, T. Transition in post-communist states: Triple or Quadruple? Politics 2001, 21, 168-177. [CrossRef]

21. Tsenkova, S. Venturing into unknown territory: Strategic spatial planning in post-socialist cities. Urban Chall. 2011, 22, 5-21. [CrossRef]

22. Stanilov, K. Taking stock of post-socialist urban development: A recapitulation. In The Post-Socialist City: Urban Form and Space Transformation in Central and Eastern Europe; Stanilov, K., Ed.; Springer: Dordrecht, The Netherlands, 2007; pp. 3-17.

23. Geertman, S.; Stillwell, J. Planning Support Systems: Content, Issues and Trends. In Planning Support Systems Best Practice and New Methods; Geertman, S., Stillwell, J., Eds.; Springer: Dordrecht, The Netherlands, 2009; pp. 1-26.

24. Zhang, L.; Geertman, S.; Hooimeijer, P.; Lin, Y. The usefulness of a web-based participatory planning support system in Wuhan, China. Comput. Environ. Urban Syst. 2019, 74, 208-217. [CrossRef]

25. Pan, H.; Zhang, L.; Cong, C.; Deal, B.M.; Wang, Y. A dynamic and spatially explicit modeling approach to identify the ecosystem service implications of complex urban systems interactions. Ecol. Indic. 2019, 102, 426-436. [CrossRef]

26. Pan, H.; Deal, B. Reporting on the performance and usability of planning support systems-Towards a common understanding. Appl. Spat. Anal. Policy 2019, 12, 1-23. [CrossRef] 
27. Pan, H.; Page, J.; Zhang, L.; Chen, S.; Cong, C.; Destouni, G.; Kalantari, Z.; Deal, B. Using comparative socio-ecological modeling to support Climate Action Planning (CAP). J. Clean. Prod. 2019, 232, $30-42$. [CrossRef]

28. Brown, G.; Raymond, C.M. Methods for identifying land-use conflict potential using participatory mapping. Landsc. Urban Plan. 2014, 122, 196-208. [CrossRef]

29. Brown, G.; Kangas, K.; Juutinen, A.; Tolvanen, A. Identifying environmental and natural resources management conflict potential using participatory mapping. Soc. Nat. Resour. 2017, 30, 1458-1475. [CrossRef]

30. Karimi, A.; Brown, G. Assessing multiple approaches for modelling land-use conflict potential from participatory mapping data. Land Use Policy 2017, 67, 253-267. [CrossRef]

31. Hesperger, A.; Iojă, C.; Steiner, F.; Tudor, C.A. Comprehensive consideration of conflicts in the land-use planning process: A conceptual contribution. Carpath. J. Earth Environ. Sci. 2015, 10, 5-13.

32. Iojă, C.L.; Niță, M.R.; Vânău, G.O.; Onose, D.A.; Gavrilidis, A.A. Using multi-criteria analysis for the identification of spatial land-use conflicts in the Bucharest Metropolitan Area. Ecol. Ind. 2014, 42, 112-121. [CrossRef]

33. Grădinariu, S.R.; Iojă, C.L.; Stupariu-Pătru, I.; Hesperger, A. Are spatial planning objectives reflected in the evolution of urban landscape patterns? A framework for the evaluation of spatial planning outcomes. Sustainability 2017, 9, 1279. [CrossRef]

34. Tudor, C.A.; Iojă, I.C.; Stupariu, I.; Niță, M.R.; Hesperger, A. How successful is the resolution of land-use conflicts? A comparison of cases from Switzerland and Romania. Appl. Geogr. 2014, 47, 125-136. [CrossRef]

35. Iojă, C.L.; Hossu, C.A.; Niță, M.R.; Onose, D.A.; Badiu, D.L.; Manolache, S. Indicators for environmental conflict monitoring in Natura 2000 sites. Proced. Environ. Sci. 2016, 32, 4-11. [CrossRef]

36. Rusu, M.; Florian, V.; Tudor, M.; Chitea, M.; Chitea, L.; Roșu, E. Land related disputes and conflicts in Romania. Agric. Econ, Rural Dev. 2011, VIII, 127-145.

37. Petrescu-Mag, R.M.; Petrescu, D.C.; Azadi, H.; Petrescu-Mag, I.V. Agricultural land use conflict management-Vulnerabilities, law restrictions and negotiation frames. A wake-up call. L. Use Policy 2018, 76, 600-610. [CrossRef]

38. Nedović-Budić, Z. Adjustment of planning practice to the new eastern and central European context. J. Am. Plan. Assoc. 2001, 67, 38-52. [CrossRef]

39. Ianos,, I.; Sirodoev, I.; Pascariu, G. Land-use conflicts and environmental policies in two post-socialist urban agglomerations: Bucharest and Chișinău. Carpath. J. Earth Environ. Sci. 2012, 7, 125-136.

40. Vesalon, L.; Crețan, R. Cyanide kills!: Environmental movements and the construction pf environmental risk at Roșia Montană. Area 2013, 45, 442-451. [CrossRef]

41. Florea, I. The Ups and Downs of a Symbolic City: The Arhitectural Heritage Protection Movement in Bucharest. In Urban. Grassroots Movements in Central and Eastern Europe; Jacobsson, K., Ed.; Ashgate: London, UK, 2015; pp. 55-78.

42. Tashakkori, A.; Teddlie, C. Handbook of Mixed Methods in Social and Behavioural Research; Sage: Thousand Oaks, CA, USA, 2003.

43. Shmueli, D. Framimg in geographical analysis of environmental conflicts: Theory, methodology and three case studies. Geoforum 2008, 39, 2048-2061. [CrossRef]

44. Foucault, M. Archaelogy of knowledge; Routledge: London, UK, 2010.

45. Entman, R. Framing: Toward Clarification of a Fractured Paradigm. J. Commun. 1993, 43, 51-58. [CrossRef]

46. Van Dijk, T.A. Introduction: The Study of Discourse. In Discourse Study. A Multidisciplinary Introduction; van Dijk, T.A., Ed.; Sage: London, UK, 2010; pp. 1-7.

47. Torre, A.; Melot, R.; Magsi, H.; Bossuet, L.; Cadoret, A.; Caron, A.; Darly, S.; Jeanneaux, P.; Kirat, T.; Pham, H.V.; et al. Identifying and measuring land-use and proximity conflicts: Methods and identification. SpringerPlus 2014, 3, 1-35. [CrossRef]

48. Khan, A.; Quynh, L.X.; Canters, F.; Corijn, E. Comparative Analysis and Assessment of Environmental Conflicts: A Synoptic Overview of Methodological Developments. In Environmental Conflicts in Coastal Urban Areas: Towards a Strategic Assessment Framework for Sustainable Development; Khan, A., Quynh, L.X., Canters, F., Corijn, E., Eds.; SECOA FP7; Casa Editrice Università La Sapienza: Roma, Italy, 2013; pp. 35-93.

49. Bryman, A. Social Research Method; Oxford Univesity Press: Oxford, UK, 2004.

50. Wengraf, T. Qualitative Research Interviewing: Biographic Narrative and Semistructured Methods; Sage: London, UK, 2001. 
51. Dey, I. Qualitative Data Analysis; Routledge: London, UK, 1993.

52. Sinclair, Stéfan and Geoffrey Rockwell. 2016. Voyant Tools. Available online: http://voyant-tools.org/ (accessed on 12 May 2019).

53. National Institute of Statistics 2019. Tempo Online Statistics. Available online: http://statistici.insse.ro/shop/ ?lang=en (accessed on 31 July 2019).

54. Nae, M.; Dumitrache, L. Post-Socialist Urban Changes and Role Strain in Assessing the Quality of Life: The Case of Bucharest, Romania. In Multidimensional Approach to Quality of Life Issues. A Spatial Analysis; Sinha, B.R.K., Ed.; Springer: Singapore, 2019; pp. 373-395.

55. Suditu, B.; Nae, M.; Neguț, S.; Gheorghilaș, A. Responsibilities and limits of local governement actions against users of public services of planning and sustainable territorial development in Romania. Amfi. Econ. 2014, XIV, 146-163.

56. Ianos, I.; Sorensen, A.; Merciu, C. Incoherence of urban planning policy in Bucharest: Its potential for land-use conflict. Land Use Policy 2017, 60, 101-112. [CrossRef]

57. Hesperger, A.; Oliveira, E.; Pagliarin, S.; Palka, G.; Verburg, P.; Bolliger, J.; Grădinaru, S. Urban land-use change: The role of strategic spatial planning. Glob. Environ. Chang. 2018, 51, 32-42. [CrossRef]

58. Coppens, T. Understanding land-use conflicts in strategic urban projects: Lessons from Gent Sint-Pieters. In Strategic Spatial Projects. Catalyst for Change; Oosterlynck, S., Van den Broeck, J., Albrechts, L., Moulaert, F., Verhetsel, A., Eds.; Routlegde: London, UK, 2010; pp. 189-293.

59. Matei, E.; Dumitrache, L.; Vijulie, I.; Nae, M.; Onețiu, A.N. Evaluating sustainability of urban development of the small towns in Romania. SGEM 2011 Conf. Proc. 2011, 3, 1065-1072.

60. Matei, E.; Dumitrache, L.; Manea, G.; Vijulie, I.; Tarlă, L.; Matei, D. Urban sustainable development of the Romanian small towns in local communities and authorities' perception Romania. SGEM 2013 Conf. Proc. 2013, 2, 347-356.

61. Brenner, N.; Peck, J.; Theodore, N. Variegated neoliberalization: Geographies, modalities, pathways. Glob. Netw. 2010, 102, 182-222. [CrossRef]

62. Law No. 50/1991 on Authorizing the Execution of Construction Works; modified and updated by the Law 292/2018; Monitorul Oficial 1043/2018; Monitorul Oficial Publishing House: Bucharest, Romania, 2018.

63. Law No. 350/2001 on Territorial Planning and Urbanism; modified and completed by OG 27/2008; Monitorul Oficial 373/2001; Monitorul Oficial Publishing House: Bucharest, Romania, 2001.

64. Cinà, G. Bucureşti de la sat la Metropolă. Identitate Urbană şi noi Tendinţe/Bucharest from Village to Metropolis. Urban. Identity and New Trends; Editura Capitel: Bucharest, Romania, 2010.

65. OG 27/2008 for Modifying and Completing; The Law No.350/2001 on Territorial Planning and Urbanism; Monitorul Oficial 628/2008; Monitorul Oficial Publishing House: Bucharest, Romania, 2008.

66. Sager, T. Neo-liberal urban planning policies: A litterature survey 1990-2010. Prog. Plan. 2011, 76, 147-199. [CrossRef]

67. Asociația Salvați Bucureștiul. Bucureștii, un Dezastru Urbanistic [Bucharest, a planning disaster]. 2008. Available online: https://salvatibucurestiul.wordpress.com/ (accessed on 8 August 2019).

68. Tigănaș, S. Urbanismul derogatoriu. Arhitectura 1906, 2012, 11.

69. Derer, P. Urbanism in transition. Urban New Ser. 2010, 7-8, 128.

70. Bold, A. Aspiraţia de civilizaţie urbană a Bucureștiului depinde de performanţa centrului de proiectare urbană, A B. Arhit Bucur. 2016, 56/2, 42-56.

71. OUG 7/2011 for Modifying and Completing; The Law No.350/2001 on Territorial Planning and Urbanism; Monitorul Oficial 111/2011; Monitorul Oficial Publishing House: Bucharest, Romania, 2011.

72. Law No. 114/1996 Housing Law; modified by OG 40/1997 and by Law 14/1997 and Republished; Monitorul Oficial 393/1997; Monitorul Oficial Publishing House: Bucharest, Romania, 1997.

73. OG 26/2000 for Associations and Foundations; Monitorul Oficial 39/2000; Monitorul Oficial Publishing House: Bucharest, Romania, 2000.

74. Pruitt, D.G.; Kim, S.H. Social Conflict: Escalation, Stalemate, and Settlement; McGraw-Hill: New York, NY, USA; London, UK, 2004.

75. Kriesberg, L. Constructive Conflicts from Escalation to Resolution; Rowman Littlefield: Oxford, UK, 2003.

76. Fürst, C.; Helming, K.; Lorz, C.; Müller, F.; Verburg, P. Integrated land-use and regional resource management-A cross-disciplinary dialogue on future perspectives for a sustainable development of regional resources. J. Environ. Manag. 2013, 127, S1-S5. [CrossRef] 
77. Fürst, C.; Opdam, P.; Inostroza, L.; Luque, S. Evaluating the role of ecosystem services in participatory land use planning: Proposing a balanced score card. Landsc. Ecol. 2014, 29, 1435-1446. [CrossRef]

78. Allmendinger, P. Planning Theory, 2nd ed.; Palgrave: London, UK, 2009.

79. Nikolaidu, S.; Klöti, T.; Tappert, S.; Drilling, M. Urban gardening and green space governance on the eve of urban densification: Towards new collaborative planning practices and hybrid forms of public space. Urb. Plan. 2016, 1, 5-19. [CrossRef]

80. OECD. The Governance of Land Use. Policy Highlights. 2017. Available online: https://www.oecd.org/cfe/ regional-policy/governance-of-land-use-policy-highlights.pdf (accessed on 30 May 2019).

81. Breuste, J.; Haase, D.; Elmqvist, T. Urban landscapes and ecosystem services. In Ecoystem Services in Agricultural and Urban Landcapes; Wratten, S., Sandhu, H., Cullen, R., Constanza, R., Eds.; Wiley Blackwell: Oxford, UK, 2013; pp. 83-104.

82. Jim, C.Y. Green-space preservation and allocation for sustainable greening of compact cities. Cities 2004, 21, 311-320. [CrossRef]

83. Suditu, B.; Nae, M.; Negut, S.; Dumitrache, L.; Gheorghilaş, A. Suburban Landscape in Romania: From forting-up to informal-up and limits of Public Action. Eu. J. Sci. Theol. 2014, 10, 125-138.

84. Artmann, M.; Kohler, M.; Meinel, G.; Gan, J.; Iojă, C.I. How smart growth and green infrastructure can mutually support each other-A conceptual framework for compact and green cities. Ecol. Ind. 2019, 96, 10-22. [CrossRef]

85. Forrester, J. Planning in the face of conflict: Negotiation and mediation strategies in local land use regulation. J. Am. Plan. Assoc. 1987, 53, 303-314. [CrossRef]

86. Order 2.701/2010 for the Methodology on Public Information and Consultation Considering the Development/Revision of Master Plans and Planning; Monitorul Oficial 47/2011; Monitorul Oficial Publishing House: Bucharest, Romania, 2011.

87. OAR. Raport pentru București. Editura PIM, Iași. 2018. Available online: https://www.oar-bucuresti.ro/ documente/Raportul-pentru-Bucuresti_2018.pdf (accessed on 15 June 2019).

88. OUG 51/2018 for Modifying and Completing; the Law No.350/2001 on territorial planning and urbanism and prorogation of law; Monitorul Oficial 520/2018; Monitorul Oficial Publishing House: Bucharest, Romania, 2018.

89. Takahashi, L.M. Activism. In International Encyclopedia of Human Geography; Kitchin, R., Thrift, N., Eds.; Elsevier: Oxford, UK, 2009; pp. 1-6.

90. Routledge, P. Activist Geography. In International Encyclopedia of Human Geography; Kitchin, R., Thrift, N., Eds.; Elsevier: Oxford, UK, 2009; pp. 7-14.

91. Taylor, N. Legibility and aesthetics in urban design. J. Urban Des. 2009, 14, 189-202. [CrossRef]

92. Snow, D.A. Framing and Social Movements. In The Wiley-Blackwell Encyclopedia of Social and Political Movements; Snow, D.A., Porta, D.D., Klandermans, B., McAdam, D., Eds.; Wiley-Blackwell: Oxford, UK, 2013; pp. 470-475.

93. Gregory, D. Geographical Imaginations; Blackwell: Oxford, UK, 1994.

94. Wylie, J.W. Poststructuralist Theories, Critical Methods and Experimentation. In Approaches in Human Geography; Aitken, S., Valentine, G., Eds.; Sage: London, UK, 2006; pp. 298-311.

95. Nash, N.; Lewis, A.; Griffin, C. Not In Our Front Garden: Land Use Conflict, Spatial Meaning and the Politics of Naming Place. J. Commun. Appl. Soc. Pscychol. 2010, 20, 44-56. [CrossRef]

96. Tuan, Y. Space and Place: The Perspective of Experience; Edward Arnold: London, UK, 1977.

97. Stokowski, P.A. Languages of places and discourses of power: Constructing new senses of power. J. Leis. Res. 2002, 11, 133-145.

98. Flyvberg, B.; Richardson, T. Planning and Foucault. In search of the dark side of planning theory. In Planning Futures: New Directions for Planning Theory; Allmendiger, P., Tewdwr-Jones, M., Eds.; Routledge: London, UK, 1998; pp. 44-62.

(C) 2019 by the authors. Licensee MDPI, Basel, Switzerland. This article is an open access article distributed under the terms and conditions of the Creative Commons Attribution (CC BY) license (http://creativecommons.org/licenses/by/4.0/). 